\title{
Thioflavicoccus mobilis gen. nov., sp. nov., a novel purple sulfur bacterium with bacteriochlorophyll $b$
}

\author{
Johannes F. Imhoff ${ }^{1}$ and Norbert Pfennig ${ }^{2}$
}

1 Institut für Meereskunde, Düsternbrooker Weg 20, D-24105 Kiel, Germany

2 Primelweg 12, D-88662 Überlingen, Germany
Author for correspondence: Johannes F. Imhoff. Tel: +49431697 3850. Fax: +49431565876. e-mail: jimhoff@ifm.uni-kiel.de

\begin{abstract}
A novel phototrophic purple sulfur bacterium was isolated from a flat, laminated microbial mat in a salt marsh near Woods Hole, Massachusetts, USA. The cells were monotrichously flagellated motile cocci with internal photosynthetic membranes of the tubular type. The main photosynthetic pigments were bacteriochlorophyll $b$ and the carotenoid $3,4,3^{\prime}, 4^{\prime}$ tetrahydrospirilloxanthin. The marine bacterium showed optimal growth in the presence of $\mathbf{2} \%$ salts. It was obligately phototrophic and strictly anaerobic. It grew photoautotrophically and photoassimilated acetate, pyruvate and ascorbate as the only organic substrates. In the presence of sulfide, elemental sulfur globules were formed inside the cells. Elemental sulfur was further oxidized to sulfate. The DNA base composition of the new bacterium was $66.5 \mathrm{~mol} \% \mathrm{G}+\mathrm{C}$. The $16 \mathrm{~S}$ rDNA nucleotide sequence was most similar to strains of Thiococcus pfennigii, there being approximately $92-93 \%$ sequence similarity. The new bacterium is described as a new species and a new genus, and the name Thioflavicoccus mobilis is proposed; the type strain is $8321^{\top}$ (= ATCC 700959').
\end{abstract}

Keywords: phototrophic purple sulfur bacteria, Thioflavicoccus mobilis gen. nov., sp. nov., Chromatiaceae, bacteriochlorophyll $b$, tubular membranes

\section{INTRODUCTION}

The first purple sulfur bacterium found to contain bacteriochlorophyll $b$ as the major photosynthetic pigment and with the main in vivo absorption maximum at $1020 \mathrm{~nm}$ was described as a Thiococcus species (Eimhjellen et al., 1967). This bacterium differed from all other photosynthetic bacteria on the basis of the internal photosynthetic membranes of tubular structure. The cells were non-motile cocci, contained sulfur globules, and did not contain gas vesicles. Strains of Thiococcus were isolated from sediments of lakes and rivers but also from marine habitats containing sulfide. This bacterium was included, later, in the genus Thiocapsa Winogradsky (1888) as Thiocapsa pfennigii (Eimhjellen, 1970). However, on the basis of $16 \mathrm{~S}$ rDNA sequences, it was significantly different from the type species of this genus, Thiocapsa roseopersicina, and was reclassified as Thiococcus pfennigii (Imhoff et

The EMBL accession numbers for the 165 rDNA sequences of strains 8320 and strain $8321^{\top}$ are AJ010125 and AJ010126, respectively. al., 1998). Only a few strains of the Chromatiaceae containing bacteriochlorophyll $b$ have been isolated so far, such as the recently described bacteria from alkaline soda lakes in Siberia, which were described as Thioalkalicoccus limnaeus (Bryantseva et al., 2000).

In sandy intertidal sediments of the Great Sippewissett Salt Marsh on Cape Cod (MA, USA), flat, laminated microbial mats of unusual thickness regularly developed. During the sampling period in the summer of 1986, these mats were about $10 \mathrm{~mm}$ thick and comprised four to five distinctly coloured layers (Nicholson et al., 1987). Phototrophic purple sulfur bacteria from the central pink layer and the peach-coloured layer immediately below were analysed. The bacteria of the peach layer consisted of small spirilloid bacteria that were classified as Rhodospira trueperi (Pfennig et al., 1997), as well as motile and non-motile cocci resembling Thiococcus pfennigii (with respect to the presence of bacteriochlorophyll $b$ and bundles of tubular internal membranes). Both types of coccoid bacteria were isolated in pure culture. This paper reports on the properties of the new, motile, coccoid, 
purple sulfur bacterium containing bacteriochlorophyll $b$, and on its genetic relationship to other purple sulfur bacteria.

\section{METHODS}

Source of organisms. The coccoid bacteria were isolated from deep-agar dilution series that had been inoculated with a peach-coloured sample of the laminated microbial mats from Great Sippewissett Salt Marsh, Cape Cod, MA, USA. A detailed description of these microbial mats has been given by Nicholson et al. (1987).

Isolation and cultivation. Pure cultures were obtained using repeated deep-agar dilution series (Pfennig, 1978). The basal medium used for isolation and further cultivation of the bacterium contained (per litre distilled water): $0.25 \mathrm{~g} \mathrm{KH}_{2} \mathrm{PO}_{4}, \quad 0.4 \mathrm{~g} \mathrm{NH}_{4} \mathrm{Cl}, \quad 0.35 \mathrm{~g} \mathrm{KCl}, \quad 20.0 \mathrm{~g} \mathrm{NaCl}$, $2.8 \mathrm{~g} \mathrm{MgSO}_{4} .7 \mathrm{H}_{2} \mathrm{O}, 0.25 \mathrm{~g} \mathrm{CaCl}_{2} .2 \mathrm{H}_{2} \mathrm{O}, 1.5 \mathrm{~g} \mathrm{NaHCO}_{3}$, $0.3 \mathrm{~g} \mathrm{Na}_{2} \mathrm{~S} .9 \mathrm{H}_{2} \mathrm{O}, 1 \mathrm{ml}$ vitamin solution (Pfennig \& Trüper, 1981) and $1 \mathrm{ml}$ trace-element solution SL 12 (Overmann et al., 1992). The basal medium was sterilized, the $\mathrm{pH}$ was adjusted to $7 \cdot 2-7 \cdot 3$ and then the medium was aseptically distributed into culture vessels as described by Pfennig \& Trüper (1981). The purity of cultures was checked microscopically and by using growth tests in AC medium (Difco).

Cultures were grown phototrophically in $100 \mathrm{ml}$ screwcapped bottles with autoclavable rubber seals. Cultures were incubated at $20-22{ }^{\circ} \mathrm{C}$ at a light intensity of $300-5001 \mathrm{x}$ from a tungsten lamp. The light intensity was checked in the 400-700 nm range with a Metrolux K light sensor (Metrawatt). The addition of sterile pyruvate solution to a final concentration of $5 \mathrm{mM}$ was used to obtain high cell yields. Stock cultures were stored at $4{ }^{\circ} \mathrm{C}$ in the dark.

Growth experiments were performed in duplicate in $20 \mathrm{ml}$ screw-capped tubes with autoclavable rubber seals. Electron donors and carbon sources were aseptically added to each tube, from sterile stock solutions, to the final concentrations indicated. The utilization of organic carbon sources was tested in the presence of hydrogen carbonate and sulfide in the media. Growth was followed by measuring the optical density at $650 \mathrm{~nm}$ with a Bausch \& Lomb Spectronic 70 photometer.

Electron microscopy. For negative staining, cells were treated with a $3 \%$ aqueous solution of uranyl acetate. For ultrathin sections, cells were prefixed in glutaraldehyde, fixed in $\mathrm{OsO}_{4}$ solution, stained with uranyl acetate in $75 \%$ acetone, embedded in Spurr medium, sectioned and then post-stained with lead acetate. Electron microscopy was carried out by Dr H. Lünsdorf (GBF, Braunschweig, Germany).

Pigment and sulfur analyses. Absorption spectra were recorded with a Lambda 2 spectrophotometer (PerkinElmer). The identification of carotenoids was carried out by means of TLC, as described by Eichler \& Pfennig (1986), using carotenoids of Thiococcus pfennigii as a reference (Schmidt, 1978). Sulfide was measured colorimetrically (Trüper \& Schlegel, 1964) and sulfate was determined turbidometrically (Dodgson, 1961).

DNA analysis. DNA was isolated using the method of Marmur (1961). The $\mathrm{G}+\mathrm{C}$ content (mol \%) of the DNA was determined by Dr J. Floßdorf (Braunschweig, Germany) according to Floßdorf (1983). Cell material for 16S rDNA sequencing was taken from 1-2 ml well-grown liquid cul- tures. DNA was extracted and purified by using the QIAGEN genomic DNA buffer set. The PCR amplification and the 16S rDNA sequencing were done as described earlier (Imhoff et al., 1998). Recombinant Taq polymerase was used for the PCR, which was started with the primers 5'GTTTGATCCTGGCTCAG-3' and 5'-TACCTTGTTACGACTTCA-3' (positions 11-27 and 1489-1506, according to the Escherichia coli $16 \mathrm{~S}$ rRNA numbering of the International Union of Biochemistry). Sequences were obtained by cycle sequencing with the SequiTherm sequencing kit (Biozym and the chain-termination reaction (Sanger et al., 1977), using an automated laser fluorescence sequencer (Pharmacia). Sequences were aligned using the CLUSTAL W program (Thompson et al., 1994). The alignment length was from position 29 to position 1381 (according to $E$. coli numbering). The distance matrix was calculated on the basis of the algorithm according to Jukes \& Cantor (1969) with the DNADIST program within the PHYLIP package (Felsenstein, 1989). The FITCH program in the PHYLIP package fitted a tree to the evolutionary distances.

\section{RESULTS}

\section{Natural habitat and isolation}

During the 1986 'Microbial Diversity' summer course at the Marine Biological Laboratory, Woods Hole, MA, USA, samples were taken from the peachcoloured layer of a laminated microbial mat at Great Sippewisset Salt Marsh, Cape Cod, MA, USA. The material was suspended in sterile culture medium and used as the inoculum for a deep-agar dilution series with basal medium plus $3 \mathrm{mM}$ acetate and $1 \%$ washed agar. After two weeks of incubation in the light,

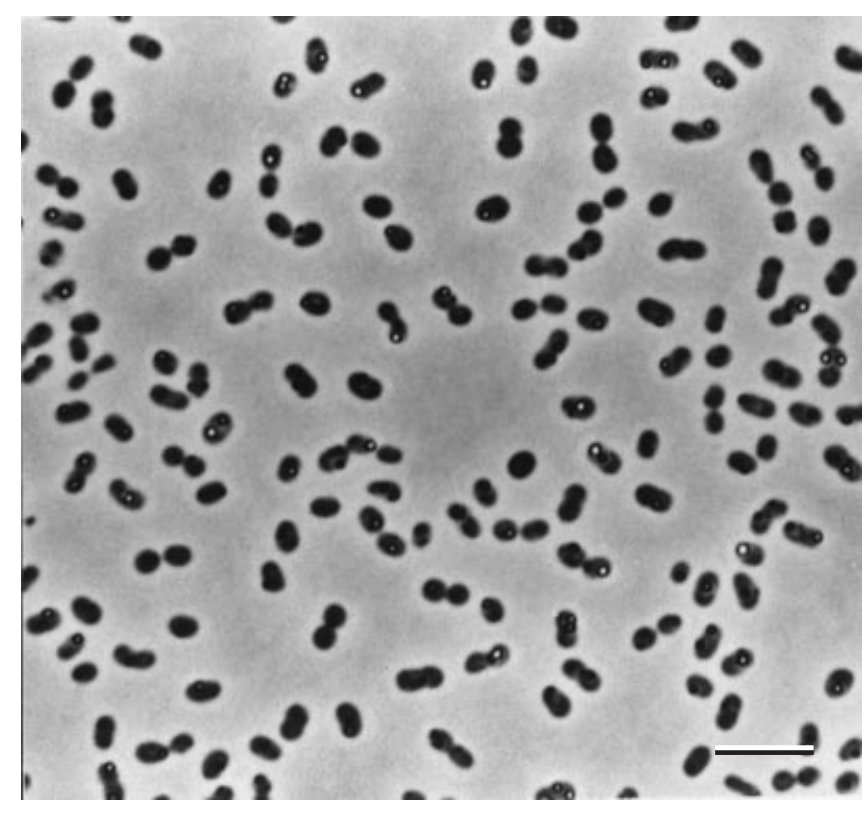

Fig. 1. Phase-contrast photomicrograph of strain $8321^{\top}$ grown photoautotrophically with sulfide. Different stages of cell division are seen. Some cells contain globules of elemental sulfur. Bar, $5 \mu \mathrm{m}$. 


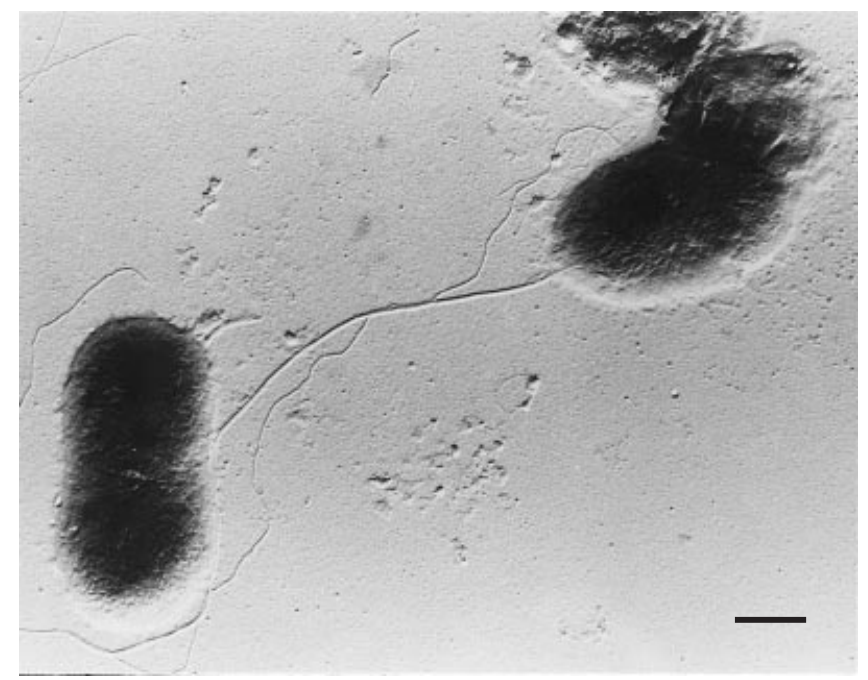

Fig. 2. Electron photomicrograph of negatively stained cells of strain $8321^{\top}$ showing monopolar-monotrichous flagella and pili. Bar, $0.5 \mu \mathrm{m}$. Courtesy of H. Lünsdorf, GBF, Braunschweig, Germany.

various types of pinkish, reddish and yellowish-beige colonies developed. Individual colonies were picked and studied microscopically. The majority of the yellowish-beige colonies contained coccoid non-motile cells. Only a few colonies consisted of highly motile cocci. Single colonies were used as inocula for second and third deep-agar dilution series to obtain pure cultures of strains 8320 (coccoid, non-motile) and strain $8321^{\mathrm{T}}$ (coccoid, motile), which were maintained as stock cultures and used for further studies. As strain 8320 resembled Thiococcus pfennigii, strain $8321^{\mathrm{T}}$ was studied in more detail.

\section{Morphology and fine structure}

In well-growing cultures, individual cells of strain $8321^{\mathrm{T}}$ were $0 \cdot 8-1 \cdot 0 \mu \mathrm{m}$ in diameter. Before division by binary fission, rod-shaped to diplococcus-shaped division stages occurred (Fig. 1). The cells were highly motile and stained Gram-negative. In negatively stained preparations, monopolar monotrichous flagella were observed (Fig. 2). Electron microscopic examination of ultrathin sections revealed an intracellular photosynthetic membrane system of the tubular type (Fig. 3). The membrane system resembled that of Thiococcus pfennigii (Eimhjellen et al., 1967) and Thioalkalicoccus limnaeus (Bryantseva et al., 2000). Ultrathin sections also revealed an outer membrane and a cytoplasmic membrane characteristic of Gramnegative bacteria (Fig. 3).

\section{Pigments}

Phototrophically grown cultures of strain $8321^{\mathrm{T}}$ appeared yellowish-beige to orange-brown in colour. The absorption spectrum of intact cells was similar to that

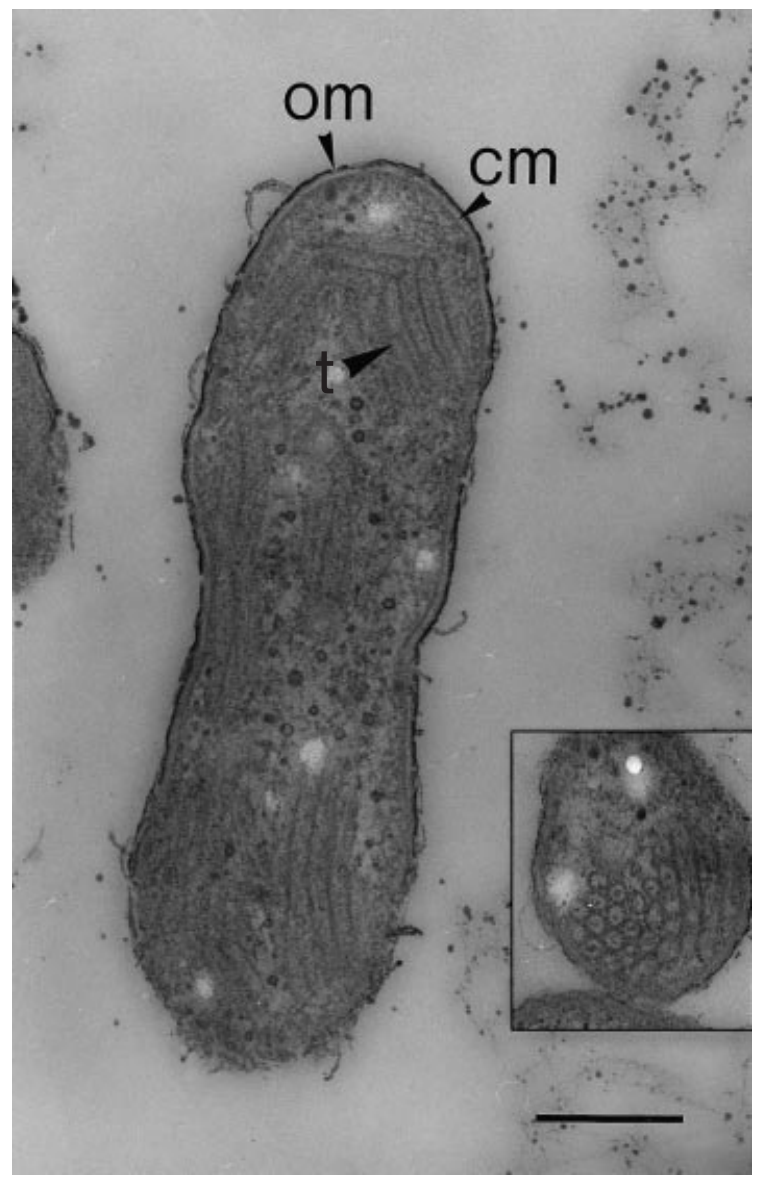

Fig. 3. Electron photomicrograph of an ultrathin section of strain $8321^{\top}$ showing tubular internal membrane structures in longitudinal section ( $t$ ) and in cross-section (inset). om, Outer membrane; $\mathrm{cm}$, cytoplasmic membrane. Bar, $0.5 \mu \mathrm{m}$. Courtesy of H. Lünsdorf, GBF, Braunschweig, Germany.

of Thiococcus pfennigii (Eimhjellen et al., 1967). The main absorption maximum at approximately $1025 \mathrm{~nm}$ quite clearly indicates the presence of bacteriochlorophyll $b$. In pigment extracts, bacteriochlorophyll $b$ was identified by co-chromatography with pigments from Thiococcus pfennigii. The in vivo maxima at 530, 492 and $462 \mathrm{~nm}$ resemble those of the carotenoids of Thiococcus pfennigii (Aasen \& Liaaen-Jensen, 1967) and indicate the presence of 3,4,3',4'-tetrahydrospirilloxanthin. Co-chromatography of pigment extracts with those from Thiococcus pfennigii allowed identification of the main carotenoid as 3,4,3', $4^{\prime}$-tetrahydrospirilloxanthin (Schmidt, 1978).

\section{Physiological properties}

Photolithoautotrophic growth of strain $8321^{\mathrm{T}}$ occurred under anoxic conditions in the light with hydrogen sulfide and elemental sulfur as electron donors. Thiosulfate was not used. The bacterium was strictly anaerobic and obligately phototrophic. No growth occurred in the dark under oxic or microoxic 
Table 1. Substrate utilization and characteristic properties of strain $8321^{\top}$ in comparison to the most closely related bacteria, Thiococcus pfennigii and Thioalkalicoccus limnaeus

All strains had tubular internal membranes, bacteriochlorophyll $b$, and 3,4,3', $4^{\prime}$-tetrahydrospirilloxanthin as the main carotenoid; all strains used sulfide, $\mathrm{S}^{0}$, acetate and pyruvate as substrates; none required vitamins and none was able to use thiosulphate. The following additional substrates were tested (concentrations $5 \mathrm{mM}$ ), but were not used by strain $8321^{\mathrm{T}}$ : arginine, butyrate, benzoate, valerate, glycerol, glycolate, glucose, gluconate, glutamate, caproate, caprylate, crotonate, malonate, mannitol, methanol, ethanol, propanol, tartrate, formate, citrate, 2-oxoglutarate, acetoin, 2,3-butanediol and ethylene glycol.

\begin{tabular}{|c|c|c|c|}
\hline Property/substrate & $\begin{array}{c}\text { Thioflavicoccus mobilis } \\
\text { strain } 8321^{\mathrm{T}}\end{array}$ & $\begin{array}{c}\text { Thiococcus pfennigii } \\
\text { strain DSM } 226\end{array}$ & $\begin{array}{c}\text { Thioalkalicoccus limnaeus } \\
\text { strain A26 }\end{array}$ \\
\hline Cell shape & Coccus & Sphere & Sphere \\
\hline Cell size & $0 \cdot 8-1 \cdot 0$ & $1 \cdot 2-1 \cdot 5$ & $1 \cdot 3-1 \cdot 8$ \\
\hline Motility & Monopolar flagella & Non-motile & Non-motile \\
\hline Salt optimum $(\%)$ & 2 & $0 \cdot 5-2 \cdot 0$ & 5 \\
\hline $\mathrm{pH}$ optimum & $7 \cdot 2-7 \cdot 4$ & $7 \cdot 2-7 \cdot 4$ & $8 \cdot 8-9 \cdot 5$ \\
\hline DNA G $+C$ content $(\mathrm{mol} \%)$ & $66 \cdot 5$ & $69 \cdot 4-69 \cdot 9$ & $63 \cdot 6-64 \cdot 8$ \\
\hline \multicolumn{4}{|l|}{ Substrates used: } \\
\hline Propionate & - & + & + \\
\hline Fructose & - & + & - \\
\hline Ascorbate & + & + & - \\
\hline Peptone & - & $(+)$ & NA \\
\hline Casamino acids & - & $(+)$ & - \\
\hline Lactate & - & + & - \\
\hline Succinate & - & + & + \\
\hline Malate & - & + & + \\
\hline Fumarate & - & + & $(+)$ \\
\hline
\end{tabular}

NA, No data available.

conditions in the presence of organic compounds. In the presence of sulfide and bicarbonate, acetate, pyruvate and ascorbate were photoassimilated. This limited substrate utilization contrasts with the larger substrate spectrum of Thiococcus pfennigii. Substrate utilization by both bacteria is shown in Table 1 .

Growth factors were not required. During growth on sulfide, sulfur globules accumulated inside the cells and were oxidized further to sulfate as the final oxidation product. Growth was dependent on the addition of $\mathrm{NaCl}$, the optimum being at $2 \% \mathrm{NaCl}$. Cultures grew well at a light intensity of $500 \mathrm{~lx}$ from a $40 \mathrm{~W}$ tungsten lamp and in the temperature range $25-30{ }^{\circ} \mathrm{C}$.

\section{Genetic properties}

The DNA base composition of strain $8321^{\mathrm{T}}$ was $66.5 \mathrm{~mol} \% \mathrm{G}+\mathrm{C}$. According to $16 \mathrm{~S}$ rDNA sequence data, the new isolate belongs to a group of bacteria within the Chromatiaceae containing tubular internal membranes and bacteriochlorophyll $b$. The sequence of the 16S rRNA gene indicates that the closest relationship is to Thiococcus pfennigii, with sequence similarities of only $91.8 \%$ for strain DSM 226 (8013) and $92.8 \%$ for strain 8320 (Fig. 4). The sequence similarity to strains of Thioalkalicoccus limnaeus is below $92 \%$.

\section{DISCUSSION}

In deep-agar dilution tubes from the peach-coloured layer of a laminated microbial mat, yellowish-beige colonies were dominant in all dilution steps. In most of the cases, suspensions of individual colonies of this type contained non-motile coccoid cells with internal sulfur globules characteristic of Thiococcus pfennigii. Surprisingly, a few colonies contained motile coccoid cells. Therefore, initially the question arose as to whether there are motile variants of the non-motile Thiococcus pfennigii or whether the motile cocci represented a separate and new taxon. The results presented in this paper and summarized in Table 1 demonstrated that, apart from motility, many other traits of strain $8321^{\mathrm{T}}$ are different from those of the typical Thiococcus pfennigii strain DSM 226 (8013). Apparent similarities in cell shape, colour of colonies, pigment content and internal membrane structure were counteracted by other significant differences. Only acetate, pyruvate and ascorbate were used as organic substrates by strain $8321^{\mathrm{T}}$, whereas Thiococcus pfennigii strains were generally able to utilize a number of additional organic compounds. Also, the $\mathrm{G}+\mathrm{C}$ content $(\mathrm{mol} \%)$ of the DNA of strain $8321^{\mathrm{T}}$ was significantly lower than that of Thiococcus pfennigii. Furthermore, the genetic relationship between the motile strain, $8321^{\mathrm{T}}$, and strains of Thiococcus pfennigii (strains DSM 226 and 8320) and Thioalkalicoccus 


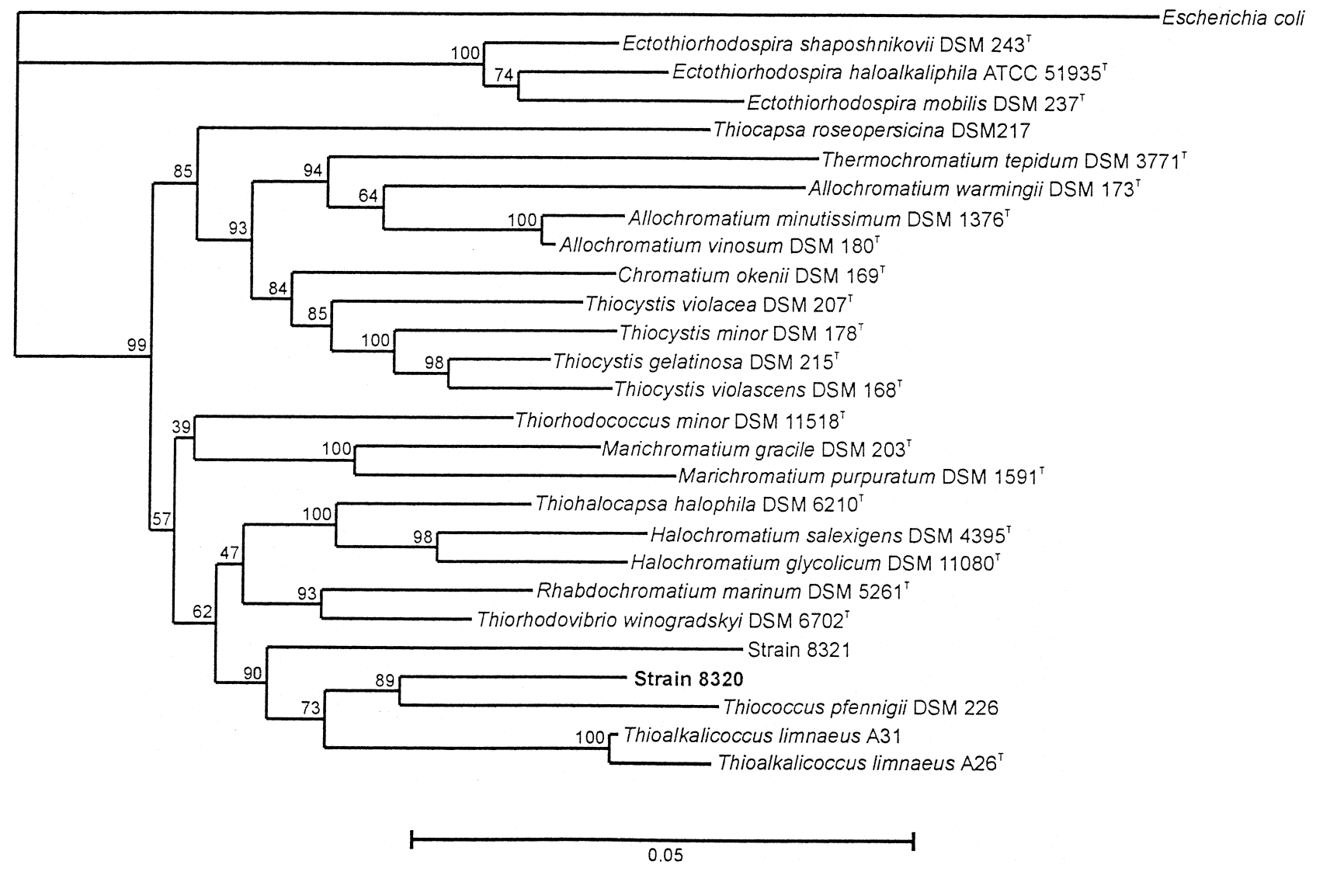

Fig. 4. Genetic relatedness of strain $8321^{\top}$ to Thiococcus pfennigii (strains DSM 226 and 8320 ) and Thioalkalicoccus limnaeus (strains A26 and A31) as well as to other purple sulfur bacteria, based on 16S rDNA sequence similarities. Numbers at the nodes give confidence values of bootstrap analyses with 100 resamplings.

limnaeus (strains A26 and A31), based on the nucleotide sequences of the 16S rDNA (Fig. 4), indicated that strain $8321^{\mathrm{T}}$ cannot be considered as a motile variant of Thiococcus pfennigii or as a new species of the genera Thiococcus and Thioalkalicoccus. The sequence similarity of strain $8321^{\mathrm{T}}$ to the closest relative, Thiococcus pfennigii, is only $91 \cdot 8-92 \cdot 8 \%$. This is at a level that is generally accepted for differentiation between genera. Therefore we propose that the motile strain $8321^{\mathrm{T}}$ should be placed in a new genus and species, for which the name Thioflavicoccus mobilis is proposed.

\section{Description of Thioflavicoccus gen. nov.}

Thioflavicoccus (Thi'o.fla'vi.coc'cus. Gr. n. thios sulfur; L. masc. adj. flavus golden-yellow, beige; L. masc. n. coccus sphere; M.L. masc. n. Thioflavicoccus beige-yellow coccus with sulfur).

Cells are spherical with diplococcus-shaped division stages, motile by flagella, and multiply by binary fission. Gram-negative; belong to the $\gamma$-Proteobacteria. Contain internal photosynthetic membranes of tubular shape. Photosynthetic pigments are bacteriochlorophyll $b$ and carotenoids. Obligately phototrophic and strictly anaerobic. Photolithoautotrophic growth under anoxic conditions in the light, with sulfide and elemental sulfur as electron donors. During oxidation of sulfide, elemental sulfur is transiently stored inside the cells in the form of highly refractile globules; the final oxidation product is sulfate. In the presence of sulfide and bicarbonate, simple organic substrates are photoassimilated. Mesophilic bacteria, growing well at $20-30{ }^{\circ} \mathrm{C}$ and neutral $\mathrm{pH}(\mathrm{pH}$ range $6 \cdot 5-7 \cdot 5)$ and requiring sodium chloride for optimum growth. The $\mathrm{G}+\mathrm{C}$ content of the DNA is $66.5 \mathrm{~mol} \%(\mathrm{Bd})$. The type species is Thioflavicoccus mobilis sp. nov.

\section{Description of Thioflavicoccus mobilis sp. nov.}

Thioflavicoccus mobilis (mo'bi.lis. L. adj. mobilis mobile).

Cells are coccoid, short rod-shaped to diplococcusshaped before cell division. Cocci are $0 \cdot 8-1 \cdot 0 \mu \mathrm{m}$ in diameter. Motile by monopolar monotrichous flagella. Possess an internal photosynthetic membrane system of tubular type. The colour of cell suspensions is yellowish-beige to orange-brown. The absorption spectrum of living cell suspensions exhibits maxima at 410, 462, 492, 530 and $1025 \mathrm{~nm}$, with shoulders at 602 
and $835 \mathrm{~nm}$. Photosynthetic pigments are bacteriochlorophyll $\mathrm{b}$ and 3,4,3',4'-tetrahydrospirilloxanthin as the main carotenoid. The metabolism is obligately phototrophic and strictly anaerobic. Photolithoautotrophic growth occurs in the light with hydrogen sulfide as electron donor. Globules of elemental sulfur are accumulated inside the cells. The final oxidation product is sulfate. Thiosulfate is not used. In the presence of sulfide and bicarbonate, acetate, pyruvate and ascorbate are used as organic substrates. Growth factors are not required. Sodium chloride is required for growth. Good growth occurs at $25-30{ }^{\circ} \mathrm{C}, \mathrm{pH}$ $7 \cdot 2-7 \cdot 4$, with $1-3 \% \mathrm{NaCl}$ (the optimum is at $2 \%$ ), and at a light intensity of 500 lx from a tungsten lamp. The habitat is laminated microbial mats of salt marshes. The type strain is strain $8321^{\mathrm{T}}\left(=\right.$ ATCC $\left.700959^{\mathrm{T}}\right)$.

\section{ACKNOWLEDGEMENTS}

We are indebted to Dr H. Lünsdorf (GBF, Braunschweig, Germany) for the electron microscopic studies of the fine structure and flagellation of the bacterium, and to Dr J. Süling (IFM Kiel, Germany) for $16 \mathrm{~S}$ rDNA sequence analysis and construction of the phylogenetic tree.

\section{REFERENCES}

Aasen, A. J. \& Liaaen Jensen, S. (1967). Bacterial carotenoids XXI. Isolation and synthesis of 3,4,3',4'-tetrahydrospirilloxanthin. Acta Chem Scand 21, 371-177.

Bryantseva, I. A., Gorlenko, V. M., Kompantseva, E. I. \& Imhoff, J. F. (2000). Thioalkalicoccus limnaeus gen. nov., sp. nov., a new alkaliphilic purple sulfur bacterium with bacteriochlorophyll $b$. Int J Syst Evol Microbiol 50, 2157-2163.

Dodgson, K. S. (1961). Determination of inorganic sulphate in studies on the enzymatic and nonenzymatic hydrolysis of carbohydrate and other sulphate esters. Biochem J 78, 312-329.

Eichler, B. \& Pfennig, N. (1986). Characterization of a new platelet-forming purple sulfur bacterium, Amoebobacter pedioformis sp. nov. Arch Microbiol 146, 295-300.

Eimhjellen, K. E. (1970). Thiocapsa pfennigii sp. nov., a new species of the phototrophic sulfur bacteria. Arch Mikrobiol 73, 193-194.

Eimhjellen, K. E., Steensland, H. \& Traetteberg, J. (1967). A Thiococcus sp. nov. gen., its pigments and internal membrane system. Arch Mikrobiol 59, 82-92.

Felsenstein, J. (1989). PHYLIP, phylogenetic inference package (version 3.2). Cladistics 5, 164-166.
Floßdorf, J. (1983). A rapid method for the determination of the base composition of bacterial DNA. J Microbiol Methods 1, 305-311.

Imhoff, J. F., Süling, J. \& Petri, R. (1998). Phylogenetic relationship among the Chromatiaceae, their taxonomic reclassification and description of the new genera Allochromatium, Halochromatium, Isochromatium, Marichromatium, Thiococcus, Thiohalocapsa and Thermochromatium. Int J Syst Bacteriol 48, $1129-1143$.

Jukes, T. H. \& Cantor, C R. (1969). Evolution of protein molecules. In Mammalian Protein Metabolism, vol. 3, pp. 21-132. Edited by H. M. Munro. New York: Academic Press.

Marmur, J. (1961). A procedure for the isolation of DNA from microorganisms. J Mol Biol 3, 208-218.

Nicholson, J. A. M., Stolz, J. F. \& Pierson, B. K. (1987). Structure of a microbial mat at Great Sippewissett Marsh, Cape Cod, Massachusetts. FEMS Microbiol Ecol 45, 343-364.

Overmann, J., Fischer, U. \& Pfennig, N. (1992). A new purple sulfur bacterium from saline littoral sediments, Thiorhodovibrio winogradskyi gen. nov. and sp. nov. Arch Microbiol 157, 329-335.

Pfennig, N. (1978). Rhodocyclus purpureus gen. nov. and spec. nov., a ring-shaped, vitamin $\mathrm{B}_{12}$-requiring member of the family Rhodospirillaceae. Int J Syst Bacteriol 28, 283-288.

Pfennig, N. \& Trüper, H. G. (1981). Isolation of members of the families Chromatiaceae and Chlorobiaceae. In The Prokaryotes, pp. 279-289. Edited by H. P. Starr, H. Stolp, H. G. Trüper, A. Balows \& H. G. Schlegel. Berlin: Springer.

Pfennig, N., Lünsdorf, H., Süling, J. \& Imhoff, J. F. (1997). Rhodospira trueperi, gen. nov. and spec. nov., a new phototrophic Proteobacterium of the alpha-group. Arch Microbiol 168, 39-45.

Sanger, F., Nicklen, S. \& Coulson, A. R. (1977). DNA sequencing with chain-terminating inhibitors. Proc Natl Acad Sci U S A 74, 5463-5467.

Schmidt, K. (1978). Biosynthesis of carotenoids. In The Photosynthetic Bacteria, pp. 729-750. Edited by R. K. Clayton \& W. R. Sistrom. New York: Plenum.

Thompson, J. D., Higgins, D. G. \& Gibson, T. J. (1994). CLUSTAL W: improving the sensitivity of progressive multiple sequence alignment through sequence weighting position-specific gap penalties and weight matrix choice. Nucleic Acids Res 22, 4673-4680.

Trüper, H. G. \& Schlegel, H. G. (1964). Sulphur metabolism in Thiorhodaceae. 1. Quantitative measurements of growing cells of Chromatium okenii. Antonie Leeuwenhoek J Microbiol Serol 30, 225-238.

Winogradsky, S. (1888). Zur Morphologie und Physiologie der Schwefelbakterien. In Beiträge zur Morphologie und Physiologie der Bakterien, Heft 1. Leipzig: Felix. 